Access to Justice in Eastern Europe,

Issue 4 (8) 2020

ISSN 2663-0575 (Print)

ISSN 2663-0583 (Online)

http://ajee-journal.com

10.33327/AJEE-18-3.4

O Ovcharenko, T Podorozhna 'Lustration of Judges in Ukraine: National Insights and European Implications' (2020) 4(8) Access to Justice in Eastern Europe 226-245

10.33327/AJEE-18-3.4-a000037

\title{
JUDGE LUSTRATION IN UKRAINE: NATIONAL INSIGHTS AND EUROPEAN IMPLICATIONS
}

\author{
Ovcharenko Olena \\ Dr. Sc. (Law), Assoc. Prof. of Department of Advocacy, \\ Yaroslav Mudryi National Law University, Kharkiv, Ukraine
}

\section{Podorozhna Tetiana \\ Dr. Sc. (Law), Prof. of Department of Theory of State and Law, Lviv University of Trade and Economics, Ukraine}

Summary: 1. Introduction. - 2. International Standards of Lustration of Judges: Basic Model and Ukrainian Perspectives. - 3. Lustration, Vetting, and Assessment of Judges: European Experience and Ukrainian Perspectives. - 4. Lustration of Judges in Ukraine: Fundamental Challenges and Basic Results. - 5. Efficiency of Lustration: An Empirical Approach. - 6. Conclusions.

This article primarily focuses on the Ukrainian judge lustration, analysed from diverse aspects. Ukraine's legal lustration framework engenders two legal acts- the Law On Restoring Trust into Judicial Power in Ukraine (2014) and the law On Purification of

Received: 01.09.2020. First Revised: 10.10.2020. Second Revised: 19.11.2020. Approved: 24.11.2020. (C) 2020 Access to Justice in Eastern Europe, Olena Ovcharenko and Tetiana Podorozhna.

This work is licensed under a CC BY-NC 4.0 license.

This license allows reusers to distribute, remix, adapt, and build upon the material in any medium or format for noncommercial purposes only, and only so long as attribution is given to the creator. 
Government (2014). Social feedback on adopting these Laws, their key objectives, provided instruments and efficiency issues are discussed. This research particularly scrutinises the fundamental European lustration standards, referencing a few European countries' experiences: Albania, Bosnia and Herzegovina, Poland. Deep insight into national lustration procedures is given, considering the European Court of Human Rights' relevant rulings and the Ukrainian Constitution's provisions. Remarks on whether all lustration laws comply with the Ukrainian Constitution are offered. Addressing the High Council of Justice's precedents, a judicial body entitled to verify the judges' lustration results, an in-depth empirical analysis of those procedural results are provided. Overall, Ukrainian lustration embodies a unique phenomenon due to strong social demand formalized in specially designed regulation.

Keywords: Ukraine, lustration, judges, judicial independence, judicial reform.

\section{INTRODUCTION}

Recent events in Ukraine have unveiled the public administration system's ineffectiveness, where institutions have become vulnerable to relapses into the old Soviet order. The revival of socio-political phenomena and tendencies, such as the rule of law, respecting human rights and freedom of expression, power decentralization and party pluralism, needs support. Undoubtedly, enhanced mechanisms overcoming these challenges engenders the lustration. As a legal institution, lustration encompasses legal norms determining the procedure for implementing lustration. Restrictions, essentially, entail a person's accountability for specific actions. In lustration, various responsibility mechanisms apply. Since lustration restrictions epitomise legality, legal systems represent a primary element. ${ }^{1}$ Lustration aims to strengthen a new democratic society and facilitate human rights and rule of law.

The Law On Restoring Trust into Judicial Power in Ukraine № 1188-VII, adopted on 8 April $2014,{ }^{2}$ monitors general jurisdiction court judges and punishes those legal officials found guilty of unfairly and judicially persecuting Euromaidan protest (taking place from November 2013 until February 2014) participants. This law launched two powerful judiciary audit instruments. All heads and deputy heads of general jurisdiction courts, except the President of the Supreme Court of Ukraine (SCU), had to resign from their administrative positions from the moment the Law entered into force, 11 April 2014. This occurred in all Ukrainian courts expeditiously, with the court's senior judges temporarily executing the court presidents' administrative functions. As outlined in this Law, the judicial communities initiated new court heads' elections with the judges' meetings on a rolling basis. Consequently, all courts elected their Presidents and deputy Presidents on a new democratically. In such a revolutionary manner, the Ukrainian judiciary eradicated the traditional, non-transparent, and undemocratic court Presidential appointment by the High Council of Judges.

$1 \quad$ O Busol, "Pro vidnovlennia doviry do sudovoi systemy" ne ye zakonom pro liustratsiiu ta potrebuie doopratsiuvannia' ["'On Restoring Trust into Judicial Power in Ukraine" is not a Law on lustration and needs to be improved'], (2014) 8 Hromadska dumka pro pravotvorennia 11-20.

2 Zakon Ukrayiny 'Pro Vidnovlennya Doviry do sudovoyiy gilky vlady' 1188-VII [Law of Ukraine 'On Restoring Trust into Judicial Power in Ukraine'] [2014] Vidomosti of the Verkhovna Rada 23/870 <http://zakon3.rada.gov.ua/laws/show/1188-18> accessed 25 October 2020. 
Secondly, the Law On Restoring Trust into Judicial Power in Ukraine outlined disciplining judges who had been proved to ban Euromaidan activities or had been involved in other severe human rights or European Convention on Human Rights violations. The Temporary Specialized Commission of Vetting of Judges of General Jurisdiction Courts (Commission) was charged with investigating and verifying judicial offenses. The SCU formed this 15 -member Commission from civil society representatives, the Verkhovna Rada (Parliament) of Ukraine, and government representatives responsible for the Issues of Anticorruption Measures Police. However, this Commission, part of the High Council of the Judiciary, lacked members for various reasons. The quorum was not continuously maintained. The Law entitled citizens to file petitions against judges, allegedly violating their conventional rights and human dignity during the Euromaidan protests. The Commission held public hearings, clarifying severe judicial offenses within a procedure similar to a regular disciplinary investigation. However, this temporary agency drastically lacked human resources and time, initially intended to function for one year. Besides, the rulings of the Commission did not have absolute power, as long as a verification of the High Council of Justice remained obligatory.

Despite implementing the Law's vetted instruments restoring judicial trust and some provisional imperfection, judiciary lustration had commenced symbolically, following most Euromaidan activists' expectations. The law 'On Purification of Government' № 1682-VII was adopted on 16 October $2014 .{ }^{3}$ Even though the aforementioned law referred mostly to the executive and law-enforcement agency representatives, some provisions directly affected judges and other judicial officials.

First, all judges had to confirm they legally acquired property ownership, including movable and immovable property, bank deposits, and numerous civil obligations. Court presidents directed implementing this instrument, controlling the asset officially published results on a unique website the Ministry of Justice administered. The latter empowered state fiscal agency officials to monitor judges' assets. Additionally, the State Judicial Administration had to reveal all Euromaidan protest participants' judicial convictions. Moreover, certain judicial officials were automatically dismissed from office when the Law 'On Purification of Government' came into force. An official ban on holding a public institutional office for five to ten years was imposed. The Ministry of Justice publically lists (https://lustration.minjust.gov.ua/register) the officials, known as a Unified State Register of Persons, Entitled for Application of Bans Provided by the Law 'On Purification of Government'. The Law restricts such judiciary as members of the High Council of Judiciary (except the SCU President), members of the Higher Qualification Commission of Judges of Ukraine, Head of the State Judicial Administration of Ukraine, first deputy head and deputy head of the State Judicial Administration of Ukraine. Furthermore, the State Security Service of Ukraine checks judges and other state officials on contact with the $\mathrm{KGB}^{4}$ or membership in the Communist Party of the former USSR's governing bodies.

3 Zakon Ukrayiny 'Pro ochyshchennya vlady' 1682-VII [The Law of Ukraine 'On Purification of Government'] [2014] Vidomosti of the Verkhovna Rada 44/2041 <http://zakon3.rada.gov.ua/laws/ show/1682-18/print1533984852614110> accessed 15 June 2019. 
Judges who failed to apply for the newly launched monitoring were discharged from office. Only 42 of 8500 Ukrainian court judges employed at the beginning of 2014 failed to meet this requirement or did not grant the vetting screenings' permission. ${ }^{5}$ All judges in office applied for the initial asset checks; however, the process was not efficient. An attempt to unveil the judges' hidden bonds with the KGB-shadows failed, mostly due to the long period since the USSR's decay. The only significant consequence of the Law 'On Purification of Government' for the judicial system's functioning was a complete shutdown, provided by the Law for the High Council of Judiciary and the Higher Qualification Commission of Judges of Ukraine, members of which had been all automatically dismissed from their offices in November 2014. For almost a year after this demonstrative public suspension, Ukraine's judiciary lacked the instruments and official mechanisms to select new judges, assess existing judges and impose sanctions upon those suspected of breaching judicial duties. However, this fact did not affect the long-term vetting of Ukrainian judiciary procedures.

International institutions and national nonprofit government organisations (NGOs) welcomed the initial legal acts to dismiss civil servants and law-enforcement agency employees, collaborating with the former undemocratic regime. However, individuals who had to comply with new verification and assessment severely criticized this process. Emphasizing the new legal provisions' anti-constitutionality, lustration opponents predicted judicial revision of the initiated public authority dismissals and adverse reactions from some European partners of Ukraine, particularly the European Court of Human Rights (ECHR). However, most of those expectations did not come to fruition. Neither did the Euromaidan activists' sincere hope the lustration would transform into a universal recipe eradicating all the problems and complications accumulating in the Ukrainian establishment since the state sovereignty and independence proclamation.

\section{INTERNATIONAL STANDARDS OF LUSTRATION OF JUDGES: BASIC MODEL}

Restoring public judiciary confidence should align with international standards. Upon entering the European Council (EC) as a full-fledged member in 1995, Ukraine has committed to creating proper judiciary functioning conditions, safeguarding court and judge independence and impartiality. ${ }^{6}$

$5 \quad$ Data about the quantity of judges in 2014 is taken from: 'Dopovyd' Golovy Verhovnogo Sudu Ukrainy Yaroslava Romaniuka na XIII z'izdi suddiv Ukrainy 12 lystopada 2015 roku' ['Report of the President of the Supreme Court of Ukraine at 13th national meeting of the judges of Ukraine, 12 November 2015'] (2015) Official web-site of the Supreme Court of Ukraine <http://www.scourt.gov.ua/clients/vsu/ vsu.nsf/(print)/AD5F6A13882B688BC2257EFB00385AD7> accessed 25 October 2020; Data about the quantity of judges, entitled to the lustration restrictions, is taken from: 'Shchorichna dopovyd za 2017 rik "Pro stan zabezpechennya nezaleznosty suddiv v Ukraini, zatverdzhena rishennyan Vyshchoiy rady pravosuddia vid” 13 liutogo 2018 roku No 463/0/15-18' ['2017 Report “On the Situation with Judicial Independence in Ukraine", adopted by the decision of the High Council of Justice on 13 February 2018, No 463/0/15-18'], (2018) Official web-site of the High Council of Justice < http://www.vru.gov.ua/add_ text/26> accessed 25 October 2020.

6 Parliamentary Assembly of the Council of Europe, Opinion No 190 (1995) Application by Ukraine for Membership of the Council of Europe' (The official web-site of the Parliamentary Assembly of the Council of Europe) <http://assembly.coe.int/nw/xml/XRef/Xref-XML2HTML-en.asp?fileid=13929\&lang=en> accessed 20 October 2020. 
European institutions elaborating exceptional standards should be considered when drafting national lustration legislation. Parliamentary Assembly Resolution No 1096 (1996) 'Measures to Dismantle the Heritage of Former Communist Totalitarian Systems' lists the members aiming to prevent misusing restrictive measures and precedents of fair trial breaches in the course of government agency purification. The Guidelines to Ensure that Lustration Laws and Similar Administrative Measures comply with the Requirements of a State-Based on the Rule of Law, incorporated into this Resolution, declare:

lustration should be administered by a specifically created independent commission of distinguished citizens nominated by the head of state and approved by parliament';

lustration should be limited to positions in which a good reason believes the subject would pose a significant danger to human rights or democracy;

in no case may a person be lustrated without being furnished with full due process protections, including, the right to counsel (assigned if the subject cannot afford one), confront and challenge the evidence used against the person, access to all available inculpatory and exculpatory evidence, present evidence, an open hearing if requested and appeal to an independent judicial tribunal;

lustration cannot be used for punishment, retribution or revenge.

The ECtHR, in its lustration precedents, generally assesses national vetting procedures focusing on safeguarding EC standards. However, the relevant rulings of the Court are not aimed to revoke national lustration laws, undermining or proclaiming as controversial to the rule of law some specific lustration restrictions. The Court analyses lustration restriction provided by the national laws following the principle of proportionality. ${ }^{8}$ Moreover, as ex-SCU Head Yaroslav Romaniuk stressed, “...the Court carefully examines lustration procedures, enshrined in the national law, and checks for their compliance with international standards, in particular, with all the guarantees of fair trial, provided by article 6 of the European Convention of Human Rights. ${ }^{\text {"9 }}$ The ECtHR reviews each lustration considering the proportionality principle and searches for possible violations of other ECHR rights, such as the right to respect private and family life, freedom of expression, right to free elections, prohibiting discrimination while imposing lustration restrictions. ${ }^{10}$

Hence, lustration procedures cannot be excluded from regular sanctions imposed upon judges. Ukrainian academicians' have corroborated such an assertion regarding the European standards of judges' legal liability. According to Larysa Vynohradova:

any procedure of legal liability of judges should be set in line with the principles of independence, impartiality, transparency, fairness, reasonable time limits and other guarantees of due process, and be determined directly by law. When evaluating any procedure applied to a judge, it is necessary to address the requirements of the due trial procedure. Absence of one or more of the above-mentioned requirements in the legal

$7 \quad$ Parliamentary Assembly (n 3, n 4).

8 Adamsons v Latvia (App no 3669/03) ECHR 24 June 2008 <https:/hudoc.echr.coe.int/ eng\#\{\%22dmdocnumber\%22:[\%22837061\%22],\%22itemid\%22:[\%22001-87179\%22]\}> accessed 27 October 2020.

9 'Interv'u Golovy Verhovnogo Sudu Ukrainy Yaroslava Romaniuka - golovnomu redactorovi zurnalu "PravoUkrainy" Oleksandru Svyatozkomy' ['The Interview of the President of the Supreme Court of Ukraine Yaroslav Romaniuk to Oleksander Svyatozkiy, Chief Editor of the Journal "Pravo Ukrainy"'] (2014) 11 Pravo Ukrainy 14-73.

10 'Praktyka organiv konstytuziynoiy urysdykziiy ta Europeys'kogo Sudu z prav lyudyny z pytan' lustrazii ['Precedents of the Constitutional Courts and European Court of Human Rights on Issues of Lustration'] (2015) 3 Visnyk Konstytuziynogo Sudu Ukrainy 120-130. 
procedure applicable to a judge raises questions to the legitimacy of the latter and may serve as a basis for appealing its results to the court. The grounds of liability and sanctions applied for judicial violation must be clearly and unambiguously established by law and cannot have a retroactive effect. ${ }^{11}$

European institutions share the same values regarding judges' legal liability, which should safeguard judicial independence. In the Statement of Principles of the Independence of the Judiciary, the Conference of Chief Justices of Central and Eastern Europe issued on 14 October 2015, two basic ideas regarding judge accountability were formulated:

- judge individual liability for failings: under para. 20 of the Statement 'judges who are presidents of chambers should not be removed as president based on adjudication by the judge or by other judges within the chamber that is deemed to be mistaken, unpopular, or disfavored;

- judiciary control over judge dismissal: under para. 21 of the Statement: 'where procedures for removing a judge by a vote of the people do not apply, procedures for removing judges must be under the judiciary's control. ${ }^{12}$

The Consultative Council of European Judges emphasized such judges liability cornerstones 'In each country, the statute or fundamental charter applicable to judges should define, as far as possible in specific terms, the failings that may give rise to disciplinary sanctions as well as the procedures to be followed (para. 71).'13 The Uinted Nationa (UN) Basic Principles on the Independence of the Judiciary of 1985 embraced:

a charge or complaint made against a judge in his/her judicial and professional capacity shall be processed expeditiously and fairly under an appropriate procedure. The judge shall have the right to a fair hearing. The examination of the matter at its initial stage shall be kept confidential, unless otherwise requested by the judge. ${ }^{14}$

Therefore, fundamentally universal judicial liability standards should be considered when introducing national special assessments. Otherwise, courts would reverse decisions dismissing judges. Lustration expert Roman David purported, that 'The process [of lustration] must be open and transparent. The secretiveness of the process and in camera hearings has proved itself to be destructive and harmful to the atmosphere of national reconciliation. ${ }^{\prime 15}$ Failure to meet those elementary values resulted in the ECtHR rulings judge lustration illustrates this position.

11 L Vynogradova, 'Urydychna vidpovidalnist suddiv zahalnyh sudiv Ukrainy' ['Judicial Liability of Judges of Courts of General Jurisdiction of Ukraine’] ( Candidate of Law thesis, Odessa Law Academy2004).

12 CEELI Institute, 'Statement of Principles of the Independence of the Judiciary' (Conference of Chief Justices of Central and Eastern Europe, 14 October 2015), <http://ceeliinstitute.org/brijuni-statement/> accessed 20 October 2020.

13 Consultative Council of European Judges, Opinion no 3 to the attention of the Committee of Ministers of the Council of Europe 'On the principles and rules governing judges' professional conduct, in particular ethics, incompatible behavior and impartiality' (The official web-site of the Consultative Council of European Judges, 19 November 2002) <https://rm.coe.int/16807475bb/> accessed 16 June 2020.

14 Basic Principles on the Independence of the Judiciary, adopted by the Seventh United Nations Congress on the Prevention of Crime and the Treatment of Offenders held at Milan from 26 August to 6 September 1985 and endorsed by General Assembly resolutions 40/32 of 29 November 1985 and 40/146 of 13 December 1985 <https://www.ohchr.org/en/professionalinterest/pages/independencejudiciary. aspx $>$ accessed 25 October 2020 .

15 R David, 'In Exchange for Truth: The Polish Lustrations and the South African Amnesty Process' (2006) 33 (1) Politikon 81-99. 
The case of Ivanovski v. 'The former Yugoslav Republic of Macedonia'16 concerned lustration proceedings against the President of the Constitutional Court of the former Yugoslav Republic of Macedonia. He had been dismissed from office, which the ECtHR found incompatible with articles 6 and 8 of the ECHR. In its decision of 21 January 2016, the Court stated the lustration proceedings in Mr. Ivanovski's case had 'raised concerns about pressure on the independence of the judiciary'. Although the national authorities proclaimed the former judge had collaborated with the secret police for about 30 years before the restrictive measures were initiated against him, the Court had reasonable doubts, that upon such a period, Mr. Ivanovski portrayed a menace to democracy. Therefore, the sanctions, restricting his professional involvement for five years, were disproportionally severe. As a result, Mr.Ivanovski was awarded 4,500 euros (EUR) in just compensation. ${ }^{17}$

\section{LUSTRATION, JUDGES VETTING AND ASSESSMENT: EUROPEAN EXPERIENCE AND UKRAINIAN PERSPECTIVES}

Lustration engenders a Latin origin, as reflected in the Roman Republic I century B.C. During this period, the 'lustratio' denoted the process within which public officials, who occupied critical army and senate posts under one dictator, were not allowed to occupy them in the future. Simply, it repressed the previous elite, without persecution and murders. Generally, lustration entailed removing elite political representatives from power and prohibiting them from occupying certain positions because they represented a political regime confessed crimes against humans.18 The core sense of the latter classifies lustration as:

- a measure to safeguard democracy when a democratic regime is established after enduring massive human rights abuses.

Brian Grodsky explained:

Lustration's popularity in Eastern Europe hinges on the theory that past abuses' qualitative and temporal nature has a determinative effect on the type of justice pursued. ... Since in communist states, large groups of people were responsible for relatively low-level abuses, criminal trials were considered to be either inappropriate or ineffective. ${ }^{19}$

- An essential part of transitional justice. ${ }^{20}$

16 Ivanovskiv 'The former Yugoslav Republic of Macedonia' (App no 29908/11) ECHR 9 May $2011<$ https:// hudoc.echr.coe.int/fre\#\{\%22itemid\%22:[\%22001-115519\%22]\}> accessed 25 October 2020.

17 The Registrar of the European Court of Human Rights, 'Lustration proceedings against Constitutional Court president were unfair' (The Official web-site of the European Court of Human Rights, 21 January 2016) , <http://www.euro-centre.eu/lustration-proceedings-constitutional-court-president-unfair/> accessed 25 October 2020.

18 S Kostezh, 'Liustratsiia: politychni chystky za shyrmoiu reform' ['Lustration: Political Purges behind the Screen of Reform'] <http://ua.112.ua/analityka/lyustraciya-politichnichistki-za-shirmoyureform-52168.html> accessed 15 June 2019.

19 B Grodsky, 'Beyond Lustration: Truth-Seeking Efforts in the Post-Communist Space' (2009) 5(2), Taiwan Journal of Democracy 21-43.

20 R Ursachi, 'In Search of a Theoretical Framework of Transitional Justice Toward a Dynamic Model' in Erna Matanović Anđelko Milardović and others (eds.), Lustration and Consolidation of Democracy and the Rule of Law in Central and Eastern Europe (Political Science Research Centre 2007, Book 5) 67-83. 


\section{According to researcher Neira Nuna Chengich:}

Lustration is considered as an alternative measure to address the issue of punishing those responsible for committing acts of aggression and repression. Such out-of-court disciplinary sanctions are generally applied by administrative agencies. Political and professional disqualifications had been one of the most popular instruments of transitional justice in Central European states since 1989 and had been frequently used as a suitable alternative for criminal prosecution. ${ }^{21}$

As UN Secretary-General Kofi A. Annan declared, 'one of the major objectives of such kind of measure is to strengthen integrity and accountability in the public sector and restore confidence in national institutions and government.'22 The EC Parliamentary Assembly added, 'the key to peaceful coexistence and a successful transition process lies in striking the delicate balance of providing justice without seeking revenge. ${ }^{23}$ Cynthia M. Horne, having explored lustration in Central and Eastern Europe, specifically Estonia, Latvia, Lithuania, the Czech Republic, Hungary, Poland, Slovakia, Bulgaria and Romania, commented on effectiveness:

Multiple measures of lustration are always highly significant and positive predictors of trust in public institutions. ... lustration has an impact, but a lesser impact on the trust in national government than on the trust indirectly targeted public institutions. The severity of lustration measures was not significant, and the timing of lustration did not appear to impact trust in government. However, economic performance measures do impact citizens' perceptions of trust in the national government, as do the levels of perceived corruption. ${ }^{24}$

- reconciling various lustration perceptions based on national peculiarities

As ex-President of the Constitutional Court of Ukraine Stanyslav Shevchuk emphasized,

lustration is simultaneously a system of measures aimed at protecting democracy and an instrument of pursuing the so-called "retroactive justice," that strives for the prosecution of persons, guilty of committing of politically motivated crimes. ${ }^{25}$

\section{According to Bardha Maxhuni and Umberto Cucchi,}

'vetting must be viewed as a complex process which needs to take into consideration political will, socio-economic context, timing, resources needed and sustainability of the process, granting that there is no "one size fits all" model. ${ }^{26}$

$21 \quad$ N Chengich, 'Mekhanizmy pravosuddya perekhidnoho periodu ta pravalyudyny v konfliktnykh i postkonfliktnykh sytuatsiyakh' ['Mechanisms of Transitional Justice and Human Rights in Conflict and Post-conflict Situations'] (Sarajevo, 5-13 December 2015) <https://helsinki.org.ua/wp-content/ uploads/2016/08/Kryminalne-peresliduvannya-vojennyh-zlochyntsiv.pdf $>$ accessed 25 October 2020.

22 'The Rule of Law and Transitional Justice in Conflict and Post-conflict Societies' (Report of the UN Secretary General) [2004] UN S 616< https://www.un.org/ruleoflaw/blog/document/the-rule-of-lawand-transitional-justice-in-conflict-and-post-conflict-societies-report-of-the-secretary-general/.

23 Parliamentary Assembly (n 3).

24 C Horne, 'Lustration and Trust in Central and East Europe: Assessing the Impact of Lustration on Trust in Public Institutions and National Government' (2012) 45(4) Comparative Political Studies 1-37 $<$ https:// doi.org/ 10.1177/ 0010414011421766 > accessed 25 October 2020.

25 S Shevchuk, 'Liustratsiia yak retroaktyvna spravedlyvist: yevropeiski standarty zakhystu prav liudyny pry perekhodi do demokratychnoho pravlinnia' ['Lustration as Retroactive Justice: European Standards For The Protection Of Human Rights During The Transition To Democratic Regime'], (2006) 2 Yurydychnyi zhurnal 20-27 <http://www.justinian.com.ua/article.php?id=2140 > accessed 25 October 2020.

26 B Maxhuni, U Cucchi, 'An Analysis of the Vetting Process in Albania'(2017) 01 Policy Analysis <http:// www.legalpoliticalstudies.org/wp-content/uploads/2017/06/An-Analysis-of-the-Vetting-Process-inAlbania.pdf $>$ accessed 25 October 2020. 


\section{UKRAINIAN JUDGE LUSTRATION: FUNDAMENTAL CHALLENGES AND BASIC RESULTS}

Once the Ukraine adopted lustration legislation, it sparked broad social discussion questioning its necessity, legality and compliance with rule of law standards. Lustration proponents referred to 'democracy, capable of defending itself', which the ECtHR corroborated in several lustration cases. ${ }^{27}$ Interpreting this concept ${ }^{28}$ in some exceptional cases, democratic countries can launch unpopular restrictive civil servant measures, reportedly collaborating with previous undemocratic regimes. Instruments aim to safeguard the rule of law values and prevent massive human rights abuses or criminal actions. One of the principal controversies to resolve the Ukrainian judge's situation entailed its advisability and constitutionality.

The related questions have been raised and detailed in the Opinion No 788/2014 of the Venice Commission, issued on 16 December 2014, 'On the Law on Government Cleansing (Lustration Law) ${ }^{29}$ '. In the official request, the SCU forwarded to the Constitutional Court of Ukraine on 16 March 2015, questioning judge lustration legitimacy. ${ }^{30}$ However, this neither affected the procedures already been launched nationally nor adopted amendments to vet the legislation. Therefore, the researcher will interpret the controversial Ukrainian judiciary's purification issues based on document analysis.

Most modern scholars identify two primary lustration concepts: political phenomenon and legal construction. The first issue in need of discussion encompasses a judge's potential to become an object of lustration restriction, a significant national concern. Some experts and top judiciary officials have claimed judges hold a special status in the checks and balances, and therefore, they should be excluded from extraordinary restrictive measures. Some Ukrainian and European mavens have expressed lustration constitutes political liability, to which judges shall not be subjected because the basis for dismissal is established in Ukraine's Constitution. Law cannot expand the listing of

27 Vogt v Germany (App no 17851/91) ECHR 26 September $1995<$ https://www.legal-tools.org/doc/6df4f3/ pdf/> accessed 10 June 2020; Naidin v Romania (App No 38162/07) ECHR 21 October $2014<$ http:// base.garant.ru/70979206/> accessed 10 October 2020 .

28 The core aspects of this concept can be traced in such sources: K Loewenstein, 'Militant Democracy and Fundamental Rights, I' (1937) 31(3) The American Political Science Review 417-432; K Loewenstein, 'Militant Democracy and Fundamental Rights, II' (1937) 31(4) The American Political Science Review 638-658; R David, 'Lyustratsiya v Ukrayini ta yevropeys'ki standarty: formuvannya demokratiyi, spromozhnoyi sebe zakhystyty' ['Lustration in Ukraine and European Standards: Formation Of Democracy, Capable of Defending Itself'] (Official Web-site of the Fair Justice Project, 2015) <http:// www.fair.org.ua/content/library_doc/FAIR_Report_Roman_David_Lust_and_Democ_2015_UKR. pdf $>$ accessed 27 October 2020.

29 Venice Commission, Opinion no 788/2014 'On the Law on Government Cleansing (Lustration Law)' (Official web-site of the Venice Commission) <http://www.venice.coe.int/webforms/documents/default. aspx?pdffile $=$ CDL-AD(2014)044-e $>$ accessed 27 June 2019

30 Resolution No 3 of the Plenum of the Supreme Court of Ukraine 'Pro zvernennya do Konstytutsiynoho Sudu Ukrayiny z konstytutsiynym podannyam schodo vidpovidnosti (konstytutsiynosti) deyakykh polozhen' Zakonu Ukrayiny № 1682-VII "Pro ochyshchennya vlady" polozhennyam chastyny tret 'oyistatti 22 , statey 38,58 , chastyny druhoyi statti 61 , chastyny pershoyi statti 62 , chastyny pershoyi statti 64 Konstytutsiyi Ukrayiny' [ 'Adress to the Constitutional Court of Ukraine with a constitutional petition on the conformity (constitutionality) of certain provisions of the Law of Ukraine No 1682-VII "On Purification of Government" to the provisions of part three of article 22, articles 38, 58, part two of article 61, part one of article 62, part 1 of article 64 of the Constitution of Ukraine"] <http://www. scourt.gov.ua/clients/vsu/vsu.nsf/(documents)/4944FCD7E14A72AEC2257E0B002FAE8E> accessed 27 October 2020. 
those grounds. Besides, article 127 of the Constitution of Ukraine outlaws any judge's political involvement. Mark S. Ellis, addressing lustration in Eastern European countries, professed, 'the implementation of lustration legislation is politically motivated.31 According to Ukrainian academics, considering the statutory guarantees of judicial independence, political responsibility measures cannot apply to judges. ${ }^{32}$

However, the ECtHR has developed an entirely different approach to lustration's legality, making it possible to apply it to judges. In the case of VOGT v. GERMANY, the Court declared:

The civil service was the cornerstone of a "democracy capable of defending itself. Its members could not, therefore, play an active role in parties, such as the DKP, that pursued anti-constitutional aims (para. 54)"; ... a democratic State is entitled to require civil servants to be loyal to the constitutional principles on which it is founded (para. 59). ${ }^{33}$

The Venice Commission follows the same approach, pointing out:

lustration procedures, despite their political nature, must be devised and carried out only by legal means, in compliance with the Constitution and taking into account European standards concerning the rule of law and respect for human rights. ${ }^{34}$

When addressing lustration measures on Ukrainian judges, its legality has readily emerged, as Ukrainian pundits have elucidated. ${ }^{35}$ Agreeing with the researchers, restrictive measures applicable to judges maintain an exclusive statutory nature. In contrast, under the Law ‘On Purification of Government’ № 1682-VII, a judge could be dismissed from office for breaching the oath (a basis of dismissal of judges, provided in article 126 of the Constitution of Ukraine before the amendments of 2016). They could also become a subject of criminal, disciplinary procedure; as for the Law 'On Restoring Trust into Judicial Power in Ukraine’ № 1188-VII, the same legal measures could be undertaken. Another restrictive instrument, Law 'On Purification of Government' No. № 1682-VII, involves dismissal from a governmental post, combined with the ban to hold a similar governmental post for five to ten years. It has proven quite problematic to define those measures' legality. Hence, any dismissal from a governmental post (including judicial position) shall be regarded as a disciplinary sanction. However, legal consequences, provided by such a dismissal, are more severe than regular punitive actions, as future career restraints accompany them. Due to this obstacle,

31 ES Mark, 'Purging the Past: the Current State of Lustration Laws in the Former Communist Bloc' (1996) 59(4) Law and Contemporary Problems 181-196.

32 O Martzelyak, M Pogoretsky, S Prilutskiy, 'Naukovo-pravovyy vysnovok shchodo pytan' vidpovidal'nosti suddiv u konteksti vidpovidnosti konstytutsiyi ukrayiny polozhen' punktu 6 chastyny pershoyi, punktiv 2, 13 chastyny druhoyi, chastyny tret'oyi statti 3 Zakonu Ukrayiny "Pro ochyshchennya vlady" No 1682-vii' ['Scientific Opinion on Issues of Liability Of Judges in the Context of the Constitutionality of paragraph 6 of part one, paragraphs 2, 13 of part two, part three of Article 3 of the Law of Ukraine "On Purification of Government" No 1682-VII"] (2015) 2 Visnyk Kryminalnogo Sudochynstva 249-263<http://vkslaw.knu.ua/images/verstka/2_2015_Na_dopomogu_yrustam_1.pdf> accessed 27 October 2020.

33 Vogt v Germany (n 47).

34 Venice Commission, Amicus Curiae Opinion no 524/2009 'Opinion on the Law on the Cleanliness of the Figure of High Functionaries of the Public Administration and Elected Persons of Albania' (Official web-site of the Venice Commission, 9-10 October 2009) para 149 <http://www.venice.coe.int/webforms/ documents/default.aspx?pdffile=CDL-AD(2009)044-e $>$ accessed 17 October 2020.

35 Martzelyak et al (n 52) 259. 
lustration dismissals can be classified as administrative sanctions. Besides, some lustration limitations can be qualified as criminal as they apply exclusively in criminal proceedings. The Law of Ukraine 'On Purification of Government', Article 55 of the Ukrainian Criminal Code was amended with a new punishment, banning occupying particular governmental posts for a term not exceeding five years. ${ }^{36}$ Considering these arguments, legislative lustration restrictions on judges' lustration combine disciplinary, administrative and criminal sanctions, demonstrating legal complexity.

Another controversial issue is the possibility of the Commission to go into the content of judicial decisions. Even though the Ukrainian Commission does not comprise a judicial body, it is entitled by law to review the legality and reasonableness of a decision the courts rendered in the Euromaidan activists' cases. Moreover, although only higher courts have exclusive powers to review judicial decisions on a procedural basis, Article 124 of the Ukraine Constitution prohibits the delegation of the court's functions and appropriates these functions by other body officials. ${ }^{37}$ In the Opinion of the Venice Commission No CDL-AD (2013) 013 'On the Temporary State Commission on miscarriages of justice of Georgia' it has been concluded:

The very idea of a process of massive examination of possible cases of miscarriage of justice by a non-judicial body raises issues regarding the separation of powers and the independence of the judiciary as enshrined in the Georgian Constitution. It may only be conceived in very exceptional circumstances (para. 11).38

The Ukrainian and Georgian government purification encompasses many standard features. However, in Ukraine, the judiciary vetting offers a starting point for judges' total reassessment, Ukrainian Constitution amendments adopted in 2016, following the Law On Judiciary and Status of Judges' changes..39 Moreover, none of the national lustration included the extrajudicial revision of decisions undertaken in Euromaidan protests.

Thus, the conducted analysis has unmasked a legal phenomenon. Lustration engenders specific immanent characteristics, namely, legislatively. Ukraine and other European countries adopted regulatory acts on government purification in due time. The principal selection criteria designated persons falling under the lustration. Lustration entails purifying all government branches from corruption threats according to a specific legal basis. This personalized phenomenon names officials at various levels not allowed to

36 This sanction could only be applicable in lustration cases; however, it has never been imposed by courts in 2014-2018.

37 Konstytutsiya Ukrayiny, adopted on 28 June 1996, with further amendments [The Constitution of Ukraine] (Official web-site of the Parliament of Ukraine) <http://zakon2.rada.gov.ua/laws/ show $/ 254 \% \mathrm{D} 0 \% \mathrm{BA} / 96-\% \mathrm{D} 0 \% \mathrm{~B} 2 \% \mathrm{D} 1 \% 80>$ accessed 10 October 2020.

38 Venice commission and directorate for justice and human dignity, joint opinion No728/2013 «On The Draft Law On The Temporary State Commission On Miscarriages Of Justice Of Georgia, (Official Web-Site Of The Venice Commission, 23 May 2013) Para. 11 < Http://Www.Venice.Coe.Int/Webforms/ Documents/?Pdf=Cdl-Ad(2013)013-E $>$ Accessed 16 October 2020.

39 Zakon Ukrayiny 'Pro vnesennya zmin do Konstytutsiyi Ukrayiny (shchodo pravosuddya)' No 1401VIII, adopted on 2 June 2016 [The Law of Ukraine 'On Amending Constitution of Ukraine (concerning justice)'] (2016) 18 Golos Ukrainy; Zakon Ukrayiny 'Pro sudoustriy i status suddiv' No 1402-VIII, adopted on 2 June 2016, with further amendments [The Law of Ukraine 'On Judiciary and Status of Judges'] (Official web-site of the Parliament of Ukraine) <http://zakon0.rada.gov.ua/laws/show/140219> accessed 17 October 2020. 
work as public authorities while also establishing a rating scale to determine the degree of criminal activity over the regime's entire existence. Lustration laws ( government purification) target the authoritarian, anti-national regime-connected politician. However, everyone falling under lustration should have the right to defense. Everyone should possess the capacity to sue and be sued under national laws. In this case, the presumption of innocence must be observed. This means no person may be charged with a criminal offense, except on the basis and under the procedure prescribed by law. This stipulates a person cannot be accused of illegal actions and cannot be lustrated until issuing a court decision.

As a legal phenomenon, lustration ensures transitional justice for transit societies, preferring democratic values in the State's organization. Lustration measures must comply with the rule of law, and fundamental freedoms, and democratic principles. It must also be accompanied by certain guarantees enabling lustration to settle political and personal accounts with opponents. In Ukraine, lustration was introduced as transitional justice. Identifying shortcomings in its functioning and further developments deserve study. Hence, the Ukrainian legislator's lustration approach remained inconsistent with the Ukrainian social and political environment's circumstances and conditions. As a result, such a perspective does not reflect an effective instrument for government purification. The Ukrainian lustration model should be modified given the specificities and interests of developing its national legal system and the political and legal situation and socio-economic challenges.

\section{LUSTRATION EFFICIENCY: EMPIRICALLY}

Georgian lustration started in 2004 with President Saakashvili coming into power. In 2004 most governmental officials were simultaneously dismissed, and new civil servants and police officers were appointed. The severe, all-inclusive lustration affected all spheres of social life. New administration rules and standards were introduced, strengthening the responsibility for corruption crimes, substantially increasing government officials' salaries, and launching adequate social security packets for newly appointed officials. As a result, the state managed to overcome total corruption and organized crime, creating a new Georgian image attractive for investing and conducting business. ${ }^{40}$ Markedly, the Georgian judge's lustration was initiated within a specific procedural framework not limited by single lustration law but marked by legislative acts adopted in various phases. During the two judicial reform stages, judges were selected with exceptional attention and responsibility, based on strictly defined criteria, like the candidate's characteristics, reputation, qualification, and analytical thinking. Considering these criteria, 186 new judges were appointed from 2005 to May $2014 .{ }^{41}$ In Ukraine, the lustration results can be

$40 \quad$ Khlabystova (n 38) 140-152; V Goshovskiy, 'The Genesis of Lustration in the World and its Significance for the Development of the Law-Based Society' (2017) 1 Legea Si Viata 33-37 <http://www.legeasiviata. in.ua/archive/2017/1-2/9.pdf> accessed 20 October 2020.

41 'Judicial Reform in Georgia' (Official web-site of the High Council of Justice of Georgia) <http://hcoj.gov. ge/en/reforms/judicial-reform> accessed 29 October 2020; N Kalandadze, 'Judicial Reform in Georgia' (2007) 9 (20) CACI Analyst <https://www.cacianalyst.org/publications/field-reports/item/11485field-reports-caci-analyst-2007-9-20-art-11485.html> accessed 30 October 2020; 'Reform in Georgia' (Policy Paper by the Administration of the Government of Georgia, October 2015) <http://gov.ge/ files/288_52140_166496_20151026ReformsinGeorgia.pdf> accessed 30 October 2020. 
regarded as quite successful. Still, they did not end up in the total shift of all Ukrainian judges. The purification processes could be characterized as relatively gradual and consistent.

According to the Law of Ukraine 'On Purification of Government', the lustration revision procedure was completed in December 2015. The Ministry of Justice filed to the High Council of Justice 70 cases recommending dismissing judges due to lustration. According to the High Council of Justice, in 2015-2016, 31 out of those 70 judges were released on the consent of the Council regardless of the verification, the Law 'On Purification of Government' envisaged (on such grounds as at their discretion, for the oath violation, on term of office expiration, on retirement, as a result of a criminal conviction). ${ }^{42}$ As the Council of Judges reported, 42 judges refused to undergo thorough lustration verifications and should have been dismissed from their posts by the High Council of Justice according to clause 5 of Article 12 of the Law 'On Purification of Government. ${ }^{\text {'43 }}$ In 2016, the High Council of Justice discharged only seven judges following the Law 'On Purification of Government.' The High Council of Judges rejected all other motions of the Ministry of Justice of Ukraine to lustrate judges due to formal defects in the Ministry's complaints. ${ }^{44}$ In such a situation, the Ministry came up with a statement most of the judges had managed to avoid lustration. ${ }^{45}$ On the contrary, the Council of Judges of Ukraine was more optimistic in evaluating the result of judicial lustration, reporting that ' $91,2 \%$ of all judges successfully fulfilled the Law "On Purification of Government" provisions and were positively assessed in the vetting procedures.' According to the Ruling of the Supreme Court Grand Chamber in the proceedings, No 800/186/17 of 31 January 2019, application of the Law of Ukraine 'On Purification of Government' in a concrete case has been recognized as legitimate, as it is 'aimed at reaching a perfect balance between needs of the democratic state and defense of democracy and human rights." ${ }^{36}$

The court presidents and vice presidents' automatic dismissals resulted in re-elections in April-September 2014, for judges restored over $80 \%$ of the lustrated leaders to administrative posts. This gave rise to public activists' criticism, challenging this lustration instrument. In most courts, the Presidents' re-elections were held democratically, avoiding scandals. Civil activists unveiled conflicts, atypically buying

42 'Zvit Vyshoyi Rady ustytsyi za resultatamy diyal'nosti u 2016 rozi' ['Report of the High Council of Justice on Results of its Work in 2016'] (Official web-site of the High Council of Justice) <https://hcj.gov. ua/sites/default/files/field/file/zvit_2016.pdf > accessed 20 October 2020.

43 Decision of the Council of Judges of Ukraine No 23 'Pro stan vykonannya suddyamy ta sudamy Ukrayiny Zakonu "Pro ochyshchennya vlady" ['On results of fulfillment of the Law of Ukraine "On Purification of Government" by the Judges of Ukraine'] (Official web-site of the Council of Judges of Ukraine, 3 March 2016), <https://court.gov.ua/userfiles/file/DSA/2018_DSA_docs/ZVIT_RSU.pdf> accessed 20 October 2020.

44 Ministry of Justice of Ukraine, Report 'On results of the Collection and Processing of the information on implementation of the Law of Ukraine "On Purification of Power" for 2 years, elaborated by Department of Lustration of the Ministry of Justice of Ukraine' (Official web-site of the Ministry of Justice of Ukraine, October 2016), <http://lustration.minjust.gov.ua/main/work_material> accessed 10 October 2020.

45 Report (n 95).

46 Decision (n 96); Ruling of the Supreme Court Grand Chamber in the proceedings No 800/186/17 of 31 January 2019 (Official web-site of the Supreme Court) <http://www.reyestr.court.gov.ua/ Review/76822787> accessed 20 October 2020. 
judges' votes, public and repeated illegal voting when the first attempt to elect the court leader failed. ${ }^{47}$

The punishment of judges involved in severe human rights abuses during the EuroMaidan protests was quite notable. As the Temporary Specialized Commission of Vetting of Judges of General Jurisdiction Courts finished their activities on 1 June 2015, 2192, complaints from citizens had been registered. The Commission found Only 309 admissible, and relevant proceedings against judges suspected of unlawful actions were started, confirming 41 judges' guilt. The Commission, handing those cases to the High Council of Justice for final verdicts, found 12 more judges guilty of minor offenses, and five judges were acquitted. Criminal proceedings were not initiated due to a lack of relevant grounds. As the Commission powers were limited to a one-year, the remaining lustration cases (305) were handed to the High Council of Judges for finalization, as Article 2 of the Law of Ukraine 'On Restoring Trust into the Judicial Power in Ukraine' prescribed. As of 1 January 2018, the High Council of Justice completed the consideration of these materials; accordingly, almost $10 \%$ of the judges accused of human rights infringements were dismissed. The High Council of Justice approved the discharge of 61 judges, of which ten of the decisions were appealed, and the court cancelled them. The High Council of Judges closed another $90 \%$ of the disciplinary proceedings, initiated by the Temporary Specialized Commission of Vetting of Judges of General Jurisdiction Courts, for various reasons. The judges were, therefore, acquitted. ${ }^{48}$ The SCU canceled some of the lustration decisions the High Council of Judges delivered upon judge appeals. For instance, in 2016, the SCU ruled to restore 23 out of 29 judges, discharged under the Law of Ukraine 'On Restoring Trust into Judicial Power in Ukraine ${ }^{\text {' } 99}$ to their posts. Those judicial decisions were delivered if the requirements of the procedure, envisaged by law, had been neglected, or the fair trial guarantees, provided by Article 6 of the ECHR, had been ignored either by the Temporary Specialized Commission of Vetting of Judges of General Jurisdiction Courts or by the High Council of Justice. ${ }^{50}$ Such a precedent was exceptional; in all other cases, the SCU denied appeals to the dismissed judges initiated and stressed the legitimate application of the Law of Ukraine On Restoring Trust into Judicial Power in Ukraine.

We have conducted an empirical study of over 115 decisions of the High Council of Judges delivered in 2015-2017 based on the application of the Law of Ukraine 'On

47 R Kuibida, 'Suchasnyy etap sudovoyi reformy: peredumovy, klyuchovi podiyi I vyklyky' ['Current Stage of Judicial Reform: Background, Key Events and Challenges'] (Official web-site of the Center of Political and Legal Reforms, 27 November 2014) <http://pravo.org.ua/files/Curent_situation.pdf> accessed 20 October 2020; I Novozhylova, 'Chy pobachyt' ukrayins'ka Femida lyustratsiyu?' ['Will Ukrainian Femida See Real Lustration?'] (Zhytomyr.Today, 21 September 2015) <http://zhitomir.today/blog/chi_ pobachit_ukrayinska_femida_lyustratsiyu-id71.html> accessed 20 October 2020.

48 R Maseko, 'Vyshcha rada pravosuddya real'no zvil'nyla lyshe 10 \% "suddiv Maydanu" ['The High Council of Justice Actually Dismissed only 10\% of "Maidan's Judges"'] (Ukrains'ka Pravda, 24 September 2017), <https://blogs.pravda.com.ua/authors/maselko/59c810d71cd38/> accessed 20 October 2020; High Council of Justice Report (n 9); Report (n 95).

49 Report (n 95).

50 O Nechytaylo,'“Skasuvannya sudom deyakykh rishen' VRYU shchodo zvil'nennya suddiv gruntuyet'sya na nedotrymanni strokiv prytyahnennya do dystsyplinarnoyi vidpovidal'nosti' ['The Annulment by the Court of Some Decisions of the HCJ on the Dismissal of Judges is Based on Failure to Comply with the Terms of Disciplinary Proceedings'] (Official web-site of the Higher Administrative Court of Ukraine, 1 March 2016) <http://www.vasu.gov.ua/123567/> accessed 20 October 2020. 
Restoring Trust into Judicial Power in Ukraine', and have revealed several trends, manifested in the process of judging of lustrated judges: ${ }^{51}$

According to a former member of the High Council of Justice, Andriy Boyko:

one of the common reasons for lustration of judges following the Law of Ukraine "On Restoring Trust into Judicial Power in Ukraine", have been documented facts of ignoring of basic legislation provisions. For example, numerous gross violations by judges of the provisions of procedural codes, the Law of Ukraine On judiciary and status of judges' and of the European Convention of Human Rights were reported in the period of the 'EuroMaidan.' Those infringements resulted in bringing activists of the protests to criminal and administrative liability for actions that would not have been prosecuted under other circumstances. ${ }^{52}$

According to our findings, 27 judges were dismissed for civil activists' detention with gross CPC violations. Such judges had not considered all the criminal indictments' circumstances when delivering decisions on activists' pre-trial detentions. In contrast, they should have investigated the case materials more thoroughly and should have assessed more evidence the prosecutors provided. Moreover, judges ignored relevant ECtHR rulings concerning pre-trial detention in criminal proceedings, delivered decisions relying exclusively on prosecutors' opinions, rejected suspects' motions, and failed to apply another restrictive pre-trial measure, bail or home-arrest envisaged by CPC.

The reasons exist, for which judges could have been summarily dismissed:

- absence of a judge in the court for a long time without compelling reasons

- travel outside the Ukraine controlled territory, without being dismissed from Ukrainian judgeship in the manner prescribed by law

- taking judicial offices under the authority of the Russian Federation [on the territory of Crimea $]^{53}$

- Ukrainian judges deliver justice on the territory of the self-proclaimed republicsLNR and DNR, in the name of those unrecognized states.

- Judges could be dismissed per the Law of Ukraine 'On Purification of Government' that envisaged the imposing restrictions for certain officials to take specific governmental posts for a period up to five years [failure to reveal asset acquisition origins]

51 All of the researched cases have been taken from the official web-sites of the High Council of Judges and the Higher Qualification Commission of Judges of Ukraine, where open registers of their decisions on imposing disciplinary sanctions on judges are placed (see <http://www.vru.gov.ua/act_list $>$; <https:// vkksu.gov.ua/ua/rishiennia-komisii/rishiennia-komisii-za-2016/> accessed 30 October 2020).

52 A Boyko, 'Vidpovidal'nist' slidchykh suddiv za porushennya norm protsesual'noho prava ta obov'yazkiv suddi shchodo zakhystu prav lyudyny u protsesi ukhvalennya sudovoho rishennya pro zastosuvannya trymannya pid vartoyu shchodo uchasnykiv Revolyutsiyi hidnosti' ['The Responsibility of Investigating Judges for Violating the Procedural Law and the Judge's Obligations Regarding the Protection of Human Rights in the Process of Adopting Court Decisions on Detention of Participants of the Revolution of Dignity'] (2016) 1 Vysnyk Assoziatzii Slidchyh suddiv Ukrainy 15-20.

53 In the decision of 24 December 2015, the High Council of Justice proved that 276 judges of the Autonomous Republic of Crimea after the annexation of the peninsula by the Russian Federation, having received citizenship of the Russian Federation, occupied judicial posts under the authority of the Russian Federation. As a result, following the decree of the Russian Federation President on their appointment, the judges started to administer justice in the Crimea. Those judges were dismissed for the breach of oath and accused of state treason. In the decision of 26 December 2016, the Higher Qualification Commission of Ukraine ordered to dismiss 100 Crimean judges who had not filed petitions to be transferred to the territory, controlled by the Government of Ukraine. 
One of the primary features of national judge lustration entailed disciplining a judge for violating human rights..$^{54}$ For example, on 5 November 2015, the High Council of Justice submitted a decision to the Ukrainian President concerning the dismissal of the Pechersk District Court of Kyiv Rodion Kireyev for oath violation. The judge became well-known for pre-trial jail detention, delivered by him in August 2011, in the criminal proceedings against the ex-Prime-Minister of Ukraine Yulia Tymoshenko. As it has been stated in the ECHR decision, delivered on 30 April 2013, Ukraine violated its obligations under Article 5 of the ECHR, claiming the pre-trial detention of Yulia Tymoshenko was 'arbitrary and unlawful.' while

'no risk of absconding was discernible from the accusations which had been advanced among the reasons for her detention: these were all of a minor nature and had not resulted in her failing to attend the hearings. In fact, the main justification for her detention indicated by the judge had been her alleged hindering of the proceedings and contemptuous behavior, which was not among the list of reasons that could justify the deprivation of liberty under Article $5 \$ 1$. Nor was it clear how the replacement of the applicant's obligation not to leave town by her detention was a more appropriate preventive measure in the circumstances. ${ }^{55}$

In January 2016, the President of Ukraine dismissed judge Kireyev from his post, although, since February 2014, he had not been in Ukrainian territory, hiding from justice in the Crimea. This case became the first national precedent of punishing a judge for a decision, the ECtHR impugned.

It would be appropriate to refer to the Venice Commission Opinion, delivered in June 2016, where judges' liability standards, preconditioned by the adverse ECtHR decision, were described. The Commission noted:

Judges' liability is indeed admissible, but only where there is a culpable mental state (intent or gross negligence) on the part of the judge. b) Liability of judges brought about by an adverse judgment by the European Court of Human Rights should therefore only be based on a national court's finding of either intentional or gross negligence on the part of the judge. The judgment of the European Court of Human Rights should not be used as the sole basis for a judges' liability. The finding of a violation of the European Court of Human Rights by the European Court of Human Rights does not necessarily mean that judges at the national level can be criticized for their interpretation and application of the law (i.e. violations may stem from systemic shortcomings in the member States, e.g. length of proceedings cases, in which personal liability cannot be raised).$^{56}$

As a former member of the High Council of Justice, Supreme Court Judge Les'ko Alla fairly underlined:

54 Article 3 of the Law of Ukraine 'On Restoring Trust into Judicial Power in Ukraine' called for disciplining of judges who, individually or collectively, took decisions contradicting the European Convention of Human Rights if those facts had been verified by the European Court of Human Rights. One of the grounds for lustration under the Law of Ukraine 'On Purification of Government' was deliverance of unlawful decisions, acts or omissions that had led to violations of human rights and fundamental freedoms, mentioned in European Court of Human Rights decisions.

55 Tymoshenko v Ukraine (App No 49872/11) ECHR 30 April 2013 <https://hudoc.echr.coe.int/ eng\#\{\%22itemid\%22:[\%22001-109460\%22]\} > accessed 20 October 2020.

56 Venice Commission, Republic of Moldova Amicus Curiae Brief for the Constitutional Court Opinion no 847/2016 'On the Right of Recourse by the State Against Judges' (Article 27 of the Law on Government Agent no.151 of 30 July 2015)' (The official web-site of the Venice Commission, 13 June 2016) <http://www.venice.coe.int/webforms/documents/default.aspx?pdffile=CDL-AD(2016)015-e> accessed 20 October 2020. 
'proceedings on disciplinary complaints against judges, backgrounded by delivered decisions of the European Court of Human Rights, where violations of Ukraine had been proved, demonstrated that most of the breaches of the European Convention of Human Rights had been caused by serious loopholes of Ukrainian legislation, which were marked by the Court as breaches of the European guidelines. ${ }^{57}$

Hence, the national court's judicial decisions, ruled in compliance with such legal provisions, should be excused from the disciplinary proceedings. On the other hand, existing procedural instruments envisage subsequent judicial decisions after the relevant European Court of Human Rights rulings. ${ }^{58}$

Finalizing the lustration proceedings analysis against judges, these measures have demonstrated relatively high effectiveness. Even though some public activists have expressed anxiety and even anger with national vetting procedures (interviews of human rights activists' leader Eugen Zaharov, ${ }^{59}$ civil activist and lawyer Roman Maselko ${ }^{60}$ and ex-vice Minister of Justice Tetyana Kozachenko, ${ }^{61}$ ) the overview of the statistical data on the application of lustration restrictions upon judges has revealed the following trends. Following the Law of Ukraine 'On Purification of Government', up to $0.1 \%$ of judges were dismissed, comparing the ratio of the total number of judges (7500) in the system general jurisdiction courts at the moment of Law adoption ${ }^{62}$ to the number of judges, released by decisions of the High Council of Judges. ${ }^{63}$ According to the Law of Ukraine 'On Restoring Trust into Judicial Power in Ukraine,' sanctions were imposed on $10 \%$ of judges whose activities were reviewed. However, the number of judges who voluntarily resigned from their judicial posts in 2015-2017 should be considered since the lustration processes may have indirectly preconditioned the departure. Most of those judges manifested their unwillingness to undergo lustration and further assessment procedures. Therefore, according to the High Council of Justice, the number of voluntary resignations did not exceed 300-400 yearly in previous years. In 2016, the Council accepted 1449 judge resignation applications. ${ }^{64}$ In 2017, an additional 360

57 A Lesko, 'Problema vykonannya rishen' Yevropeys'koho sudu z prav lyudyny: neobkhidnist' systemnoho analizu ta vprovadzhennya' ['The Problem of Implementing of the European Court of Human Rights decisions: the Call for Complex Analysis and Implementation'] (Official web-site of the High Council of Justice, 23 November 2016) <http://www.vru.gov.ua/news/1880> accessed 10 October 2020.

58 Such a revision is done by the Supreme Court in accordance with Articles 361-369 of the Code of Administrative Procedure of Ukraine. See Kodekc Admimistratyvnogo Sudochynstva Ukrayiny No 2747-IV, adopted on 6 July 2005 (with further amendments) [Code of Administrative Procedure of Ukraine] <http://zakon3.rada.gov.ua/laws/show/2747-15> accessed 20 October 2020.

59 E Zaharov, 'Zakon pro lyustratsiyu peredbachaye zvil'nennya ponad pivmil'yona derzh sluzhbovtsiv' ['The law on Lustration Demands Dismissal of More than Half a Million of Civil Servants'] (iPressUA, 30 September 2014) <http://ipress.ua/news/zakon_pro_lyustratsiyu_peredbachaie_zvilnennya_ ponad_pivmilyona_derzhsluzhbovtsiv__pravozahysnyk_87582.html> accessed 15 October 2020; Zaharov (n 67).

60 Maseko (n 101).

61 T Kozachenko, 'Kryteriyiv, za yakymy mozhna lyustruvaty suddiv, duzhe malo: Interv'yu vydannyu ZIK' ['There are Very Few Criteria that can be Used to Lustrate Judges: Interview to the Journal ZiK'] (ZIKTV Channel, 29 November 2017) <https://zik.ua/news/2017/11/29/tetyana_kozachenko_ kryteriiv_za_yakymy_mozhna_lyustruvaty_suddiv_duzhe_malo_1216133> accessed 20 October 2020.

62 Report (n 9).

63 Report (n 95); Decision (n 96); Report of the Ministry of Justice (n 97).

64 Report (n 95). 
judges resigned. ${ }^{65}$ Moreover, ordinary disciplinary procedures demonstrated similar effectiveness. According to the High Council of Justice, 96 decisions in disciplinary cases of judges were passed in 2017; in 8953 proceedings initiating judge disciplinary liability, complaints were dismissed in compliance with the Law 'On the High Council of Justice'; ${ }^{66}$ thus, slightly more than $1 \%$ of all judicial offense complaints resulted in the actual sanctions upon the judges. Comparably, addressing lustration results in Ukraine's police authorities (former militia bodies) could be a significant disappointment. As the National Police of Ukraine reports, 'a total number of 86219 police officers were reappointed, accounting for $93 \%$ of those who had been going through lustration; overall 5,436 of police officers were fired in the process of the vetting assessment; more than two thousand of dismissed police officers in 2016-2017 won their court suits, in which they had appealed their discharges. They were reimbursed more than 55 million [in Ukrainian Hrivnas] of budget funds for wrongful dismissal. ${ }^{67}$

Such a failure in militia purification was due to crucial loopholes of relevant legislation, adopted in a rush of 2014 post-revolutionary implications, without considering the necessary guarantees of due process of law Article 6 of the ECHR. ${ }^{68}$

The key aspects of Ukrainian lustration have been summarized in the ECtHR's decision in Polyakh and others v. Ukraine, delivered on 17 October 2019. The Court stressed the uniqueness of Ukrainian lustration and found loopholes in the envisaged by Government purification measure power. Notably, it was declared that 'the first three applicants' right to a fair trial had been violated because proceedings on their dismissal had lasted more than four and a half years and were still ongoing. The Court also noted the violation of Article 8 (right to respect for private and family life) of the Convention regarding all five applicants. It was no doubt that in the period when former President Viktor Yanukovych was in power, the Ukrainian civil service and democratic governance had indeed faced considerable challenges, which justified a need for reform. However, the Court found that the Law of Ukraine "On Purification of Government" was of comprehensive application and had led to the dismissal of the applicants for merely having worked in the civil service for more than a year while Mr. Yanukovych was in power or for having been a Communist Party official before 1991. The law, therefore, had no regard to the applicants' roles or whether they had been associated with any of the undemocratic acts that had taken place under the former president. ${ }^{69}$

Consequently, the ECtHR decision was based on a traditional and universally respected theory of legal liability. Any restriction measure put upon an offender should be

$65 \quad$ Report of the High Council of Justice (n 9).

66 Report of the High Council of Justice (n 9).

67 L Hryshko, 'Provalena reforma, abo dorohyy revansh militsioneriv' ['Failure to Reform, or Expensive Revenge of Ex-policemen'] (Deutsche Welle, 9 November 2017) <https://www.dw.com/ ukB2/a-41312321> accessed 30 October 2020; Report of the Ministry of Justice (n 97).

68 Y Lysianskyi, 'Zamestitel' glavy VASU Mikhail Smokovich: “Odnimi vysokimi zarplatami doveriya $\mathrm{k}$ sudam ne vernesh"' ['Vice President of the Highest Administrative Court of Ukraine, Mikhail Smokovich: "You Cannot Return Trust to the Courts only with the Means of High Remuneration"'] (Official web-site of the Highest Administrative Court of Ukraine, 4 May 2016) <http://www.vasu.gov. ua/123606/> accessed 30 October 2020.

69 Polyakh and Others $v$ Ukraine (App No 58812/15 and 4 others) ECHR 17 October $2019<$ https://hudoc. echr.coe.int/eng\#\{\%22itemid\%22:[\%22001-196607\%22]\}> accessed 30 October 2020. 
envisaged by law, individually assessed, predictable in advance and applied within due process procedures. In other cases, national and international courts could challenge any lustration measure not fitting in those standards.

\section{CONCLUSIONS}

Based on the research, several Ukrainian judge lustration conclusions have emerged: its background, legal regulation, intercourse, and results. Based on the reflections regarding its nature and understanding, lustration can be conceptualized as the measures regulated by law, aimed at verifying the past of the persons collaborating with non-democratic regimes and imposing special sanctions on these individuals to prevent their participation in state power. Specifically, judicial civil activist detentions, Ukrainian judges delivered during the Euromaidan events (November 2013-February 2014), contributed significantly to human rights activists' dissatisfaction, who were ready to introduce people's vetting of judges. Instead, in 2014 the Parliament of Ukraine adopted two lustration laws: 'On Restoring Trust into Judicial Power in Ukraine' and 'On Purification of Government'. These laws aimed to start an unprecedented judiciary purification campaign to eradicate the heritage of past undemocratic processes. Within this framework, the positive effect of implementing Ukrainian lustration substantially impacted government bodies and their officials' activities. Nevertheless, today the provisions of the Laws of Ukraine 'On Purification of Government' and 'On Restoring Trust into Judicial Power in Ukraine' are far from being appropriate. Furthermore, new legislation provisions in this domain are necessary since lustration should be legal, fair and objective to be applied within the appropriate mechanisms.

Lustration is being disputed internationally and domestically. Regarding the ECtHR concept of 'a democracy capable of defending itself ${ }^{70}$, a unique, national approach has been worked out in Ukraine. The Venice Commission identified domestic distinctiveness of the Ukrainian lustration: "The Law "On Purification of Government" differs from lustration laws adopted in other countries of Central and Eastern Europe in that it is broader in scope. It pursues two different aims. The first is protecting society from individuals who, due to their past behavior, could pose a threat to the newly established democratic regime. The second is to cleanse the public administration from individuals who have engaged in large-scale corruption. The term lustration in its traditional meaning, only covers the first process. ${ }^{71}$

Although government purification embodies a political phenomenon, it requires a competent legal framework and an appropriate executive mechanism. Otherwise, lustration might well become 'witch-hunting, directly contradicting the rule of law desirable for young democracies. That is the reason why lustration measures should be analyzed from several perspectives - value protection essential for democratic society

70 Ždanoka v Latvia (App No 58278/00) ECHR 16 March 2006 <http://associationline.org/guidebook/ action/read/chapter/4/section/jurisprudence/decision/102> accessed 28 October 2020.

71 Venice Commission, Final Opinion № 788/2014 'On the Law on Government Cleansing (Lustration Law) of Ukraine as Would Result from the Amendments, Submitted to the Verkhovna Rada on 21 April 2015' (19-20 June 2015, para. 107) <http://www.venice.coe.int/webforms/documents/?pdf=CDL$\mathrm{AD}(2015) 012-\mathrm{e}>$ accessed 22 October 2020. 
during the transition period and human rights respect and the rule of law principle since these two aspects are closely interrelated. Primarily, this can be attributed to respect for human rights could not be achieved in the absence of effective democracy because a democratic society is based on respect for fundamental human rights and freedoms. Hence, the lustration does not restrict or infringing fundamental natural rights (right to life, prohibiting torture, right to liberty and personal integrity). On the contrary, limitations imposed on the right of access to the state (public) service (government decision-making) represent the direct consequence of the period of extensive transitional changes since it concerns the persons who have compromised themselves by working with the former repressive regime. Lustration remains integral to democratization and an inevitable transitional justice component. Within this overall aim, restrictions on specific individuals who collaborated with the repressive regime remain acceptable.

Applying lustration restrictions upon judges did raise some concerns about the constitutionality of the relevant legislation. In particular, such legal principles, provided by the Constitution of Ukraine, have been questioned concerning judges: double jeopardy ban for one offense, vagueness of innocence presumption safeguards, collective guilt possibility and retroactive lustration force. Those questions are expected to be unveiled by the Constitutional Court of Ukraine. Guarantees of judicial independence outweighed most of the uncertain lustration issues provided by regular disciplinary proceedings applied following lustration legislation. Those procedures' vagueness is compliant with the limitation exclusiveness (sanctions), its temporal basis, and the democratic society's legitimate expectations after the revolutionary power shift. We should also refer to the Constitutional Court of Slovenia's opinion that in 1994 reviewed the possibility of bringing under retroactive liability (lustrating) judges who had previously delivered decisions with severe human rights and freedoms violations. The Court did admit such liability and noted, relying on the rule of law constitutional concept, that '.. the socalled lustration rule means that the right to participate in state administration may be limited (this case concerns the right to be elected on judicial post) regarding facts of cooperation with the previous non-democratic regime'; the Court mentioned that documented facts of misuses of power by a concrete judge could be a reason for councils assessing judges in selection procedures to reject such a candidate. ${ }^{72}$

Empirical insight into Ukrainian judge lustration demonstrates it has been quite successful, resulting in voluntary and compelled dismissal of up to $25 \%$ of Ukraine's general jurisdiction courts. Supplemented by Constitutional amendments of 2016 launched a completely new selection model, assessment, and judge discipline. Precedents of disciplining judges based on human rights breaches, contained in judicial decisions and attested by the ECtHR, demonstrate European aspirations of the Ukrainian judiciary.

72 Decision of the Constitutional Court of the Republic of Slovenia of 14 July 1994 cited by 'Praktyka orhaniv konstytutsiynoyiy urysdyktsiyi ta Yevropeys 'koho sudu z prav lyudyny z pytan' lyustratsiyi (prodovzhennya)' ['Precedents of Courts of Constitutional Jurisdiction and the European Court of Human Rights on Lustration (Continued)'] (2015) 3 Vysnyk Konstytuyziynogo Sudu Ukrainy (2015) 120-130. 